\title{
Statyba
}

\section{ANALYSIS OF CONSTRUCTION ON ELASTIC FOUNDATION WITH EVALUATION OF ALL SYSTEM DEAD WEIGHT}

\section{A. Grigusevičius , S. Kalanta \& A. Krutinis}

To cite this article: A. Grigusevičius, S. Kalanta \& A. Krutinis (2001) ANALYSIS OF CONSTRUCTION ON ELASTIC FOUNDATION WITH EVALUATION OF ALL SYSTEM DEAD WEIGHT, Statyba, 7:2, 115-121, DOI: 10.1080/13921525.2001.10531712

To link to this article: https://doi.org/10.1080/13921525.2001.10531712

曲 Published online: 30 Jul 2012.

Submit your article to this journal $₫$

Џ Article views: 81 


\section{KONSTRUKCIJU ANT TAMPRAUS PAGRINDO SKAIČIAVIMAS IVERTINANT VISOS SISTEMOS SAVĄJI SVORI}

\section{A. Grigusevičius, S. Kalanta, A. Krutinis}

Vilniaus Gedimino technikos universitetas

\section{Ivadas}

Konstrukcijų ant tampraus pagrindo skaičiavimas iki šiol formuluojamas kaip kontaktinis uždavinys [1, 2]. Esant tokiam formulavimui itempimy ir deformaciju būvis nagrinejjamas kontako tarp konstrukcijos ir pagrindo paviršiuje. Tačiau negalima ivertinti deformuojamo pagrindo savojo svorio itakos ir itempimu bei deformacijų pasiskirstymo pagrinde. Šio straipsnio tikslas - išspręsti šią aktualią konstrukciju ant tampraus pagrindo skaičiavimo problemą, leidžiančią patikslinti ittempimų ir deformacijų būvị sistemoje, ivertinant ne tik konstrukcijos, bet ir deformuojamo pagrindo savojo svorio įtaką. Sistema „siena-pamatas-pagrindas“ nagrinèjama tamprioje darbo stadijoje kaip atskirų kūnų sąveika. Tokios problemos formulavimas leidžia pereiti nuo kontaktinių uždavinių prie kokybiškai naujų uždavinių sprendimo, kuriais bus ivertintas itempimц ir deformaciju pasiskirstymas konstrukcijos pagrinde pagal ploti ir gyli. Straipsnyje suformuluoti matematiniai modeliai realizuoti taikant programini paketą COSMOS/M. Nustatytas plokštès sienutès ittempimų deformaciju būvis, diskretizuojant sistemą ,siena-pamatas-pagrindas“ $i$ elementus, turinčius skirtingus fizinius mechaninius rodiklius.

\section{Pagrindinés priklausomybės}

Nagrinejjamas dviejų kūnų sistemos (konstrukcijos ir deformuojamo pagrindo) itempimų ir deformaciju būvis. Sistemą sudaro konstrukcija, tūrio $V_{k}$ ir pagrindas tūrio $V_{p}$ (1 pav.). Ši sistema yra veikiama išorinès apkrovos, kurią aprašysime vektorine funkcija $\mathbf{q}(\mathbf{x}) \in S_{f}$, bei savojo svorio vektoriais funkcijomis $\mathbf{g}_{k}(\mathbf{x}) \in V_{k}$ ir $\mathbf{g}_{p}(\mathbf{x}) \in V_{p}$. Apkrovos ir savojo svorio intensyvumai bei kryptys žinomi. Ieškomą itempimų ir deformacijų būvi konstrukcijoje aprašysime vektorinėmis funkcijomis $\boldsymbol{\sigma}_{k}(\mathbf{x}) \in V_{k}$ ir $\boldsymbol{\varepsilon}_{k}(\mathbf{x}) \in V_{k}, \mathbf{u}_{k}(\mathbf{x}) \in V_{k}$. Deformuojamo pagrindo ịtempimų ir deformacijų būvi aprašysime itempimu vektorine funkcija $\boldsymbol{\sigma}_{p}(\mathbf{x}) \in V_{p}$, deformacijų vektoriumi funkcija $\varepsilon_{p}(\mathbf{x}) \in V_{p}$ ir nuosèdžių vektorine funkcija $\mathbf{s}(\mathbf{x}) \in V_{p}$. Sistemos ,konstrukcija-pagrindas“ paviršių sudaro $S=S_{f} \cup S_{p} \cup S_{u}$, kur $S_{u}$ - konstrukcijos ir pagrindo kontakto paviršius, $S_{p}$.- pagrindo kraštinis paviršius.

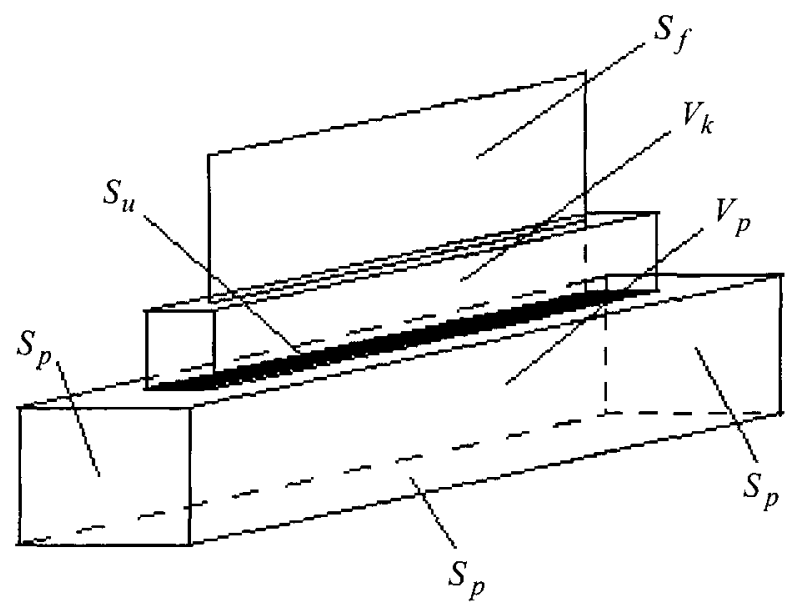

1 pav. Sistema „konstrukcija pagrindas“

Fig 1. System "construction-foundation"

Konstrukcijos ir deformuojamo pagrindo statiškai leistini itempimy vektorinès funkcijos $\boldsymbol{\sigma}_{k}(\mathbf{x}), \boldsymbol{\sigma}_{p}(\mathbf{x})$ aprašomi statikos pusiausvyros lygtimis ir statinemis kraštinėmis sąlygomis:

$$
\left.\begin{array}{cc}
-[A] \boldsymbol{\sigma}_{k}(\mathbf{x})=\mathbf{g}_{k}(\mathbf{x}) & \in V_{k}, \\
-[A] \boldsymbol{\sigma}_{p}(\mathbf{x})=\mathbf{g}_{p}(\mathbf{x}) & \in V_{p}, \\
{[N] \boldsymbol{\sigma}_{k}(\mathbf{x})=\mathbf{q}(\mathbf{x})} & \in S_{f}, \\
{[N] \boldsymbol{\sigma}_{k}(\mathbf{x})-\mathbf{p}(\mathbf{x})=\mathbf{0}} & \in S_{u}, \\
{[N] \boldsymbol{\sigma}_{p}(\mathbf{x})-\mathbf{p}(\mathbf{x})=\mathbf{0}} & \in S_{u}, \\
\mathbf{p}(\mathbf{x}) \leq \mathbf{0} & \in S_{u}, \\
{[N] \boldsymbol{\sigma}_{p}(\mathbf{x})-\mathbf{p}_{p}(\mathbf{x})=\mathbf{0}} & \in S_{p} .
\end{array}\right\}
$$


Čia diferencialinių statikos pusiausvyros lygčių operatorius

$$
[A]=\begin{array}{|c|c|c|c|c|c|}
\hline \frac{\partial}{\partial x_{1}} & & & \frac{\partial}{\partial x_{2}} & \frac{\partial}{\partial x_{3}} & \\
\hline & \frac{\partial}{\partial x_{2}} & & \frac{\partial}{\partial x_{1}} & & \frac{\partial}{\partial x_{3}} \\
\hline & & \frac{\partial}{\partial x_{3}} & & \frac{\partial}{\partial x_{1}} & \frac{\partial}{\partial x_{2}} \\
\hline
\end{array}
$$

ir statinių kraštinių sąlygų matrica

$$
[N]=\begin{array}{|l|l|l|l|l|l|}
\hline n_{1} & & & n_{2} & n_{3} & \\
\hline & n_{2} & & n_{1} & & n_{3} \\
\hline & & n_{3} & & n_{1} & n_{2} \\
\hline
\end{array}
$$

Kinematiškai leistinu poslinkių ir deformacijų vektorinés funkcijos $\mathbf{u}_{k}(\mathbf{x}), \mathbf{s}(\mathbf{x}), \boldsymbol{\varepsilon}_{k}(\mathbf{x}), \boldsymbol{\varepsilon}_{p}(\mathbf{x})$ sistemoje „konstrukcija-pagrindas“ aprašomi geometrinėmis lygtimis:

$$
\left.\begin{array}{ll}
{[A]^{T} \mathbf{u}_{k}(\mathbf{x})-\boldsymbol{\varepsilon}_{k}(\mathbf{x})=\mathbf{0}} & \in V_{k}, \\
{[A]^{T} \mathbf{s}(\mathbf{x})-\boldsymbol{\varepsilon}_{p}(\mathbf{x})=\mathbf{0}} & \in V_{p}, \\
\mathbf{u}_{k}(\mathbf{x})=\mathbf{s}(\mathbf{x}) & \in S_{u} .
\end{array}\right\}
$$

Ryšius tarp sistemos „,konstrukcija-pagrindas“ itempimų vektorinių funkcijų $\sigma_{k}(\mathbf{x}), \sigma_{p}(\mathbf{x})$ ir deformacijų vektorinių funkciju $\boldsymbol{\varepsilon}_{k}(\mathbf{x}), \boldsymbol{\varepsilon}_{p}(\mathbf{x})$ aprašysime fizinèmis lygtimis. Šas lygtis suformuluosime konstrukcijai ir tampriam pagrindui:

$$
\left.\begin{array}{l}
{\left[D_{k}\right] \sigma_{k}(\mathbf{x})=\varepsilon_{k}(\mathbf{x}) \in V_{k},} \\
{\left[D_{p}\right] \sigma_{p}(\mathbf{x})=\varepsilon_{p}(\mathbf{x}) \in V_{p} .}
\end{array}\right\}
$$

Čia $\left[D_{k}\right],\left[D_{p}\right]-$ konstrukcijos ir pagrindo fizinių lygčiu pasiduodamumo matricos, priklausančios atitinkamai nuo medžiagos tamprumo modulio $E$, defomaciju modulio $E_{0}$ ir Puasono koeficientu $v$ ir $v_{0}$. Konstrukcijos pasiduodamumo matrica:

$\left[D_{k}\right]=\frac{1}{E}$\begin{tabular}{|c|c|c|c|c|c|}
\hline 1 & $-v$ & $-v$ & & & \\
\hline$-v$ & 1 & $-v$ & & & \\
\hline$-v$ & $-v$ & 1 & & & \\
\hline & & & $2(1+v)$ & & \\
\hline & & & & $2(1+v)$ & \\
\hline & & & & & $2(1+v)$ \\
\hline
\end{tabular}

Matrica $\left[D_{p}\right]$ yra analogiškos struktūros.

Pagrindo kraštiniame paviršiuje $S_{p}$ turi būti tenkinamos kraštinès sąlygos [3]:

$$
[D] \mathbf{p}_{p}(\mathbf{x})+\mathbf{s}(\mathbf{x})=\mathbf{0} \in S_{p},
$$

kur $[D]$ - pagrindo pasiduodamumo matrica, kurios diagonaliniai elementai atvirkščiai proporcingi standumo rodikliui $C$.

\section{Pilnoji lygčių sistema tikrajam itempimų defor- macijų būviui nustatyti}

Statikos pusiausvyros, geometrinès ir fizinès lygtys bei kraštinès sąlygos (1)-(4) sudaro sistemos ,konstrukcija-pagrindas“" pilnają lygčiu sistemą, aprašančią konstrukcijos ir pagrindo tampruji itempimu ir deformaciju būvị. Eliminavus deformacijas $\boldsymbol{\varepsilon}_{k}(\mathbf{x}), \boldsymbol{\varepsilon}_{p}(\mathbf{x})$ ir itempimus $\mathbf{p}(\mathbf{x})$, ji atrodo taip:

$$
\begin{aligned}
& -[A] \boldsymbol{\sigma}_{k}(\mathbf{x})=\mathbf{g}_{k}(\mathbf{x}) \quad \in V_{k} \\
& -[A] \boldsymbol{\sigma}_{p}(\mathbf{x})=\mathbf{g}_{p}(\mathbf{x}) \quad \in V_{p}, \\
& {\left[D_{k}\right] \boldsymbol{\sigma}_{k}(\mathbf{x})-[A]^{T} \mathbf{u}_{k}(\mathbf{x})=\mathbf{0} \in V_{k},} \\
& {\left[D_{p}\right] \boldsymbol{\sigma}_{p}(\mathbf{x})-[A]^{T} \mathbf{s}(\mathbf{x})=\mathbf{0} \in V_{p},} \\
& {[D] \mathbf{p}_{p}(\mathbf{x})+\mathbf{s}(\mathbf{x})=\mathbf{0} \quad \in S_{p},} \\
& {[N] \boldsymbol{\sigma}_{k}(\mathbf{x})=\mathbf{q}(\mathbf{x}) \quad \in S_{f},} \\
& {[N] \boldsymbol{\sigma}_{k}(\mathbf{x})-[N] \boldsymbol{\sigma}_{p}(\mathbf{x})=\mathbf{0} \in S_{u},} \\
& \mathbf{u}_{k}(\mathbf{x})-\mathbf{s}(\mathbf{x})=\mathbf{0} \quad \in S_{u}, \\
& \mathbf{p}(\mathbf{x}) \leq \mathbf{0} \in S_{u} \text {. }
\end{aligned}
$$

Plokštès sienutès ant tampraus pagrindo įtempimų-deformacijų būvis šiame matematiniame modelyje aprašytas:

- statikos pusiausvyros lygtimis konstrukcijoje (5) ir pagrinde (6);

- konstrukcijos ir pagrindo geometrinèmis lygtimis (7) ir (8);

- kraštinèmis sąlygomis (9) pagrindo paviršiuje $S_{p}$;

- statinemis kraštinèmis sąlygomis (10) konstrukcijos paviršiuje $S_{f}$;

- statinès ir kinematinès darnos sąlygomis (11) ir (12) konstrukcijos ir pagrindo kontakto paviršiuje $S_{u}$;

- pagrindo reaktyvinių spaudimų ženklo ribojimo sąlyga (13). 


\section{Variacinẻs uždavinio formuluotės}

Sprendžiant tamprumo teorijos uždavinius baigtiniu elementy metodu paprastai yra realizuojama vienokia ar kitokia uždavinio variacinè formuluotè, nes tiesioginis lygčiụ sistemos sprendimas yra pernelyg sudètingas. Nagrinèjamo uždavinio kai kurias variacines formuluotes sudarome remiantis pilnutinès papildomosios energijos (Kastiljano) principu [3-5]: iš visu statiškai galimu itempimu lauku sistemoje ,konstrukcija-pagrindas" tikrasis yra tas, kuriam esant sistemos pilnutine papildomoji energija yra minimali.

Sistemos pilnutinė papildomoji energija:

$$
\begin{aligned}
& U=\frac{1}{2} \int_{V_{k}} \boldsymbol{\sigma}_{k}^{T}(\mathbf{x})\left[D_{k}\right] \boldsymbol{\sigma}_{k}(\mathbf{x}) d V_{k}+ \\
& +\frac{1}{2} \int_{V_{p}} \boldsymbol{\sigma}_{p}^{T}(\mathbf{x})\left[D_{p}\right] \boldsymbol{\sigma}_{p}(\mathbf{x}) d V_{p}+\frac{1}{2} \int_{S_{p}} \mathbf{p}_{p}^{T}(\mathbf{x})[D] \mathbf{p}_{p}(\mathbf{x}) d S_{p}
\end{aligned}
$$

o statiškai galimi itempimụ laukai aprašomi lygčiu sistema (1). Todèl remiantis Kastiljano principu gauname tokią uždavinio statinę variacinę formuluotę:

$$
\begin{aligned}
& \frac{1}{2} \int_{V_{k}} \sigma_{k}^{T}(\mathbf{x})\left[D_{k}\right] \sigma_{k}(\mathbf{x}) d V_{k}+\frac{1}{2} \int_{V_{p}} \boldsymbol{\sigma}_{p}^{T}(\mathbf{x})\left[D_{p}\right] \boldsymbol{\sigma}_{p}(\mathbf{x}) d V_{p}+ \\
& +\frac{1}{2} \int_{S_{p}} \mathbf{p}_{p}^{T}(\mathbf{x})[D] \mathbf{p}_{p}(\mathbf{x}) d S_{p} \Rightarrow \min
\end{aligned}
$$

kai:

$$
\left.\begin{array}{ll}
-[A] \boldsymbol{\sigma}_{k}(\mathbf{x})=\mathbf{g}_{k}(\mathbf{x}) & \in V_{k}, \\
-[A] \boldsymbol{\sigma}_{p}(\mathbf{x})=\mathbf{g}_{p}(\mathbf{x}) & \in V_{p}, \\
{[N] \boldsymbol{\sigma}_{k}(\mathbf{x})=\mathbf{q}(\mathbf{x})} & \in S_{f}, \\
{[N] \boldsymbol{\sigma}_{k}(\mathbf{x})-\mathbf{p}(\mathbf{x})=\mathbf{0}} & \in S_{u}, \\
{[N] \boldsymbol{\sigma}_{p}(\mathbf{x})-\mathbf{p}(\mathbf{x})=\mathbf{0}} & \in S_{u}, \\
\mathbf{p}(\mathbf{x}) \leq \mathbf{0} & \in S_{u}, \\
{[N] \boldsymbol{\sigma}_{p}(\mathbf{x})-\mathbf{p}_{p}(\mathbf{x})=\mathbf{0} \in S_{p}}
\end{array}\right\}
$$

Ji leidžia nustatyti įtempimu pasiskirstymą konstrukcijos ir pagrindo tūryje bei reaktyvinius spaudimus $\mathbf{p}_{p}(\mathbf{x})$ pagrindo paviršiuje $S_{p}$.

Lagranžo daugiklių metodu sudarome dualią uždavinio formuluotę:

$$
\begin{aligned}
& -\frac{1}{2} \int_{V_{k}} \boldsymbol{\sigma}_{k}^{T}(\mathbf{x})\left[D_{k}\right] \boldsymbol{\sigma}_{k}(\mathbf{x}) d V_{k}-\frac{1}{2} \int \sigma_{V_{p}} \boldsymbol{\sigma}_{p}^{T}(\mathbf{x})\left[D_{p}\right] \boldsymbol{\sigma}_{p}(\mathbf{x}) d V_{p}- \\
& -\frac{1}{2} \int_{S_{p}} \mathbf{p}_{p}^{T}(\mathbf{x})[D] \mathbf{p}_{p}(\mathbf{x}) d S_{p}+\int_{V_{k}} \mathbf{u}_{k}^{T}(\mathbf{x}) \mathbf{g}_{k}(\mathbf{x}) d V_{k}+ \\
& +\int_{V_{p}} \mathbf{s}^{T}(\mathbf{x}) \mathbf{g}_{p}(\mathbf{x}) d V_{p}+\int_{S_{f}} \mathbf{u}_{k}^{T}(\mathbf{x}) \mathbf{q}_{k}(\mathbf{x}) d S_{f} \Rightarrow \max
\end{aligned}
$$

kai:

$$
\left.\begin{array}{ll}
{\left[D_{k}\right] \boldsymbol{\sigma}_{k}(\mathbf{x})-[A]^{T} \mathbf{u}_{k}(\mathbf{x})=\mathbf{0}} & \in V_{k}, \\
{\left[D_{p}\right] \boldsymbol{\sigma}_{p}(\mathbf{x})-[A]^{T} \mathbf{s}(\mathbf{x})=\mathbf{0}} & \in V_{p}, \\
{[D] \mathbf{p}_{p}(\mathbf{x})+\mathbf{s}(\mathbf{x})=\mathbf{0}} & \in S_{p}, \\
\mathbf{u}_{k}(\mathbf{x})-\mathbf{s}(\mathbf{x}) \leq \mathbf{0} & \in S_{u} .
\end{array}\right\}
$$

Šio uždavinio sąlygos aprašo kinematiškai leistinų konstrukcijos poslinkių ir pagrindo nuosèdžiu laukų aibę, o tikslo funkcija, padauginta iš -1 , išreiškia deformuojamos sistemos pilnutinę potencinę energija. Todèl ekstremumo uždavinys (16)-(17) išreiškia Lagranžo principa: iš visu kinematiškai galimu poslinkiu ir nuosédžiı lauku sistemoje „,konstrukcija-pagrindas" tikrasis yra tas, kuriam esant deformuojamos sistemos pilnutiné potenciné energija minimali.

Šis matematinis modelis leidžia tiesiogiai nustatyti sistemos itempimus ir poslinkius, tačiau yra nepatogus, nes turi daug nežinomuju. Eliminuojant ittempimų funkcijas, ji galima supaprastinti. Iš (17) lygčiu sistemos gauname priklausomybes:

$$
\left.\begin{array}{ll}
\boldsymbol{\sigma}_{k}(\mathbf{x})=\left[D_{k}\right]^{-1}[A]^{T} \mathbf{u}_{k}(\mathbf{x}) & \in V_{k}, \\
\boldsymbol{\sigma}_{p}(\mathbf{x})=\left[D_{p}\right]^{-1}[A]^{T} \mathbf{s}(\mathbf{x}) & \in V_{p}, \\
\mathbf{p}_{p}(\mathbf{x})=-[D]^{-1} \mathbf{s}(\mathbf{x}) & \in S_{p} .
\end{array}\right\}
$$

Istatant šias ịtempimų funkciju išraiškas $i$ tikslo funkciją (16), gaunama tokia uždavinio kinematinè formuluoté:

$$
-\frac{1}{2} \int_{V_{k}}\left\{[A]^{T} \mathbf{u}_{k}(\mathbf{x})\right\}^{T}\left[D_{k}\right]^{-1}[A]^{T} \mathbf{u}_{k}(\mathbf{x}) d V_{k}-
$$$$
\frac{1}{2} \int_{V_{p}}\left\{[A]^{T} \mathbf{s}(\mathbf{x})\right\}^{T}\left[D_{p}\right]^{-1}[A]^{T} \mathbf{s}(\mathbf{x}) d V_{p}-
$$

$$
\begin{aligned}
& \frac{1}{2} \int_{S_{p}} \mathbf{s}^{T}(\mathbf{x})[D]^{-1} \mathbf{s}(\mathbf{x}) d S_{p}+\int_{V_{k}} \mathbf{u}_{k}^{T}(\mathbf{x}) \mathbf{g}_{k}(\mathbf{x}) d V_{k}+ \\
& \int_{V_{p}} \mathbf{s}^{T}(\mathbf{x}) \mathbf{g}_{p}(\mathbf{x}) d V_{p}+\int_{S_{f}} \mathbf{u}_{k}^{T}(\mathbf{x}) \mathbf{q}_{k}(\mathbf{x}) d S_{f} \Rightarrow \max ,
\end{aligned}
$$


kai sąlygos

$$
\mathbf{u}_{k}(\mathbf{x})-\mathbf{s}(\mathbf{x}) \leq \mathbf{0} \quad \in S_{u}
$$

Nežinomieji šiame uždavinyje yra tik kinematiniai dydžiai: konstrukcijos poslinkiai $\mathbf{u}_{k}(\mathbf{x})$ ir pagrindo nuosèdžiai $\mathbf{s}(\mathbf{x})$. Nagrinejjamam plokščiu sienučiu ant tampraus pagrindo analizès uždaviniui apribojimas $\mathbf{p}(\mathbf{x}) \leq \mathbf{0} \in S_{u}$ yra neesminis, nes maža tikimybė atsirasti tempimo itempimams po pamato padu. Atmetus $\breve{s} i$ apribojimą iš uždavinio statinès formuluotès, kinematinès formuluotès nelygybè (20) tampa griežta lygybe:

$$
\mathbf{u}_{k}(\mathbf{x})-\mathbf{s}(\mathbf{x})=\mathbf{0} \in S_{u} .
$$

Iš pateiktų matematinių modelių lengviausiai yra realizuojamas modelis (19)-(20), tuo labiau, kad jo sprendimui galima pasinaudoti esamais kompiuteriniais tamprumo teorijos uždavinių sprendimo paketais. Jis sprendžiamas baigtinių elementų metodu, naudojant geometriškai darnius baigtinius elementus, kaip pagrindinius nežinomuosius imant poslinkius baigtinių elementu mazguose. Išsprendę uždavinị (19)-(20), nustatome konstrukcijos poslinkius ir deformuojamojo pagrindo nuosèdžius, o vẻliau pagal formules (18) skaičiuojame itempimus.

\section{Skaičiavimo pavyzdys}

Šiame uždavinyje siena-pamatas-pagrindas nagrinejjami kaip vientisa sistema. Jos deformuotojo būvio analizei naudojama COSMOS/M kompiuterinè programa [6].

Sistemos deformuotojo būvio analizè atliekama pagrindą modeliuojant dviem būdais. Pirmuoju atveju diskretiniame modelyje ( 2 pav.) pagrindas yra ivertinamas kaip tūrinis stačiakampio gretasienio formos elementas, iš apačios ir šony apribotas baigtinio storio sluoksniu, deformuojamu pagal Vinklerio hipotezę, kurio standumo rodiklis $C_{1}$. Visas pagrindas yra vientisas, t. y. turi tokius pačius fizinius mechaninius rodiklius. Antruoju atveju diskretininiame modelyje visas pagrindas įvertinamas tik baigtinio storio sluoksniu, deformuojamu pagal Vinklerio hipotezę ir turinčiu standumo rodiklị $C_{2}$. Visi kiti duomenys abiem atvejams yra vienodi.

Siena: ilgis $36 \mathrm{~m}$; aukštis $10,48 \mathrm{~m}$; storis $0,8 \mathrm{~m}$; tankis $1800 \mathrm{~kg} / \mathrm{m}^{3}$; tamprumo modulis $7000000 \mathrm{kPa}$; skersinès deformacijos koeficientas 0,3 ; diskretizuota trikampio tipo baigtiniais elementais; veikia apkrovos nuo dviejų aukštų perdangu bei stogo.

Pamatas: ilgis $36 \mathrm{~m}$; aukštis $0,65 \mathrm{~m}$ (apatinès dalies), 0,89 $\mathrm{m}$ (viršutinès dalies); storis $1,0 \mathrm{~m}$ (apatinès dalies), 1,2 m (viršutinès dalies); tankis $2000 \mathrm{~kg} / \mathrm{m}^{3}$ (apatinès dalies), $1800 \mathrm{~kg} / \mathrm{m}^{3}$ (viršutinès dalies); tamprumo modulis $3542000 \mathrm{kPa}$ (apatinès dalies), $7000000 \mathrm{kPa}$ (viršutinès dalies); skersinès deformacijos koeficientas 0,3 ; diskretizuota tetraedro tipo tūriniais baigtiniais elementais.

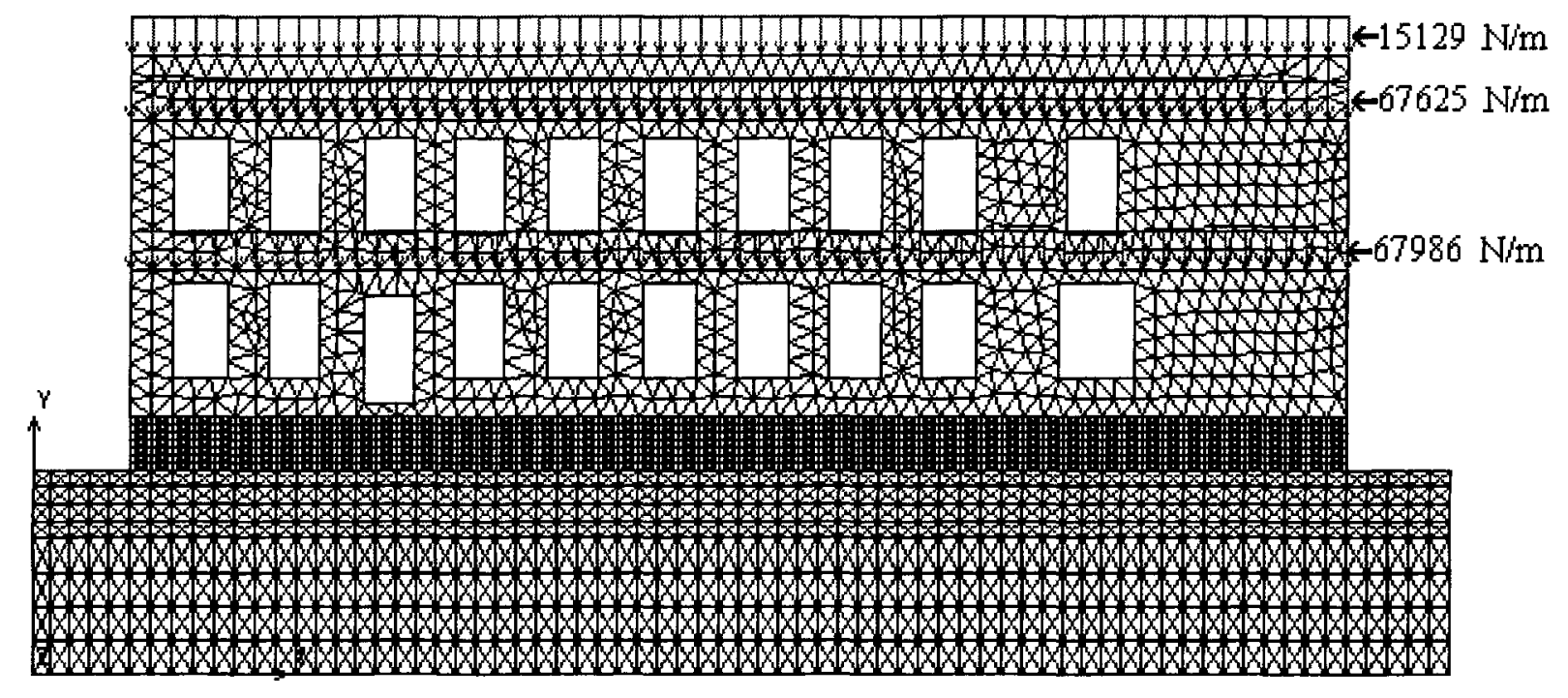

2 pav. Sistemos „siena-pamatas-pagrindas“ diskretizavimas baigtiniais elementais su pridètaja apkrova

Fig 2. Finite elements and loading of system "wall-substructure-foundation" 


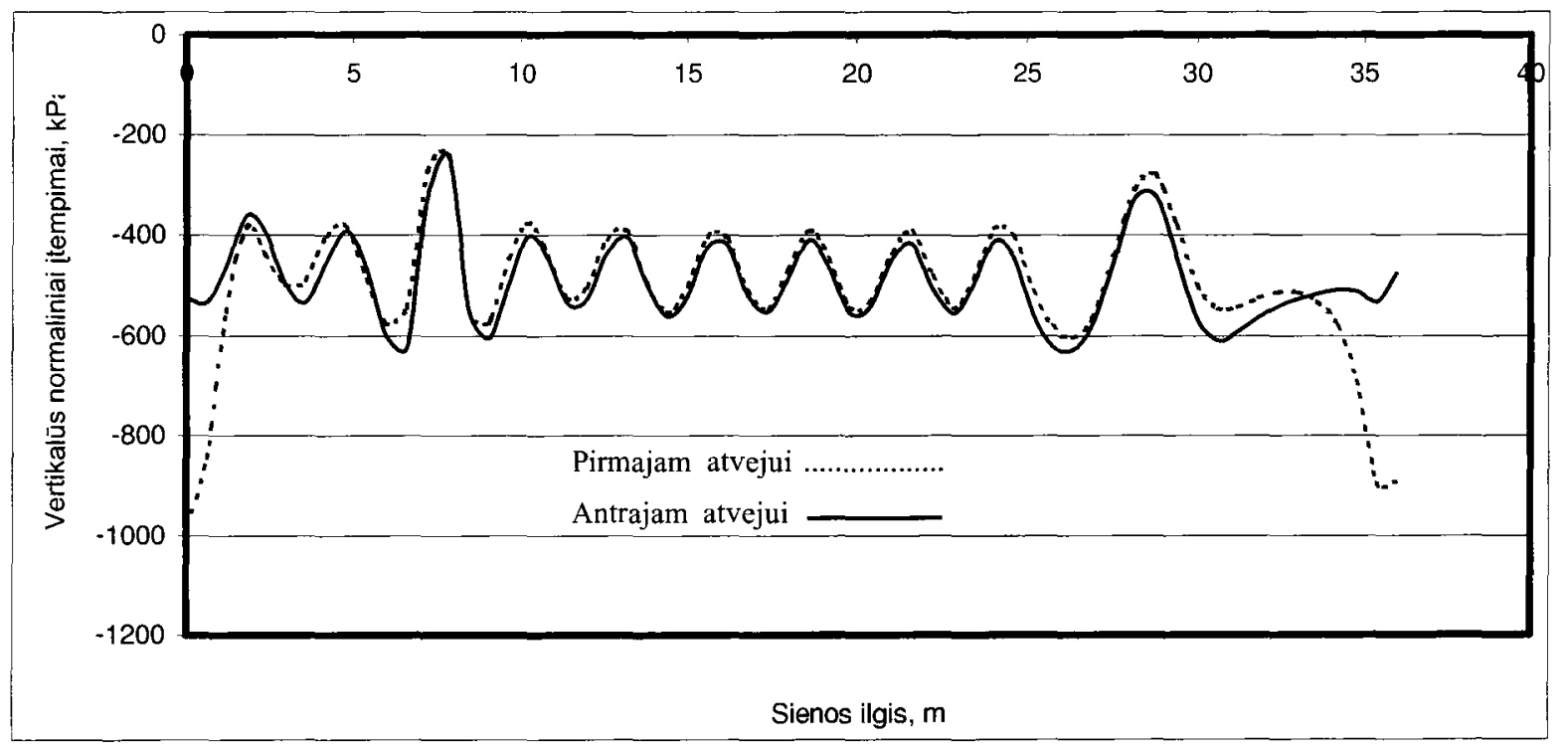

3 pav. Normaliniu itempimu $y$ ašies kryptimi pasiskirstymas ties sienos ir pamato riba

Fig 3. Distribution of normal stresses in $y$ direction at the joint of wall and substructure

Pagrindas: ilgis $42 \mathrm{~m}$; aukštis $6 \mathrm{~m}$; plotis $7,2 \mathrm{~m}$; grunto tankis $1660 \mathrm{~kg} / \mathrm{m}^{3}$; deformacijos modulis $40000 \mathrm{kPa}$; skersinès deformacijos koeficientas 0,3 ; diskretizuota tetraedro tipo tūriniais baigtiniais elementais; pagrindo standumo rodiklis bus:

Pirmajame diskretiniame modelyje:

$$
\begin{aligned}
& C_{1}=\frac{E_{0}}{\left(1-v_{0}\right)^{2} \cdot H_{s l l}}= \\
& \frac{40000}{(1-0,3)^{2} \cdot 3,6}=22676 \mathrm{kPa} / \mathrm{m} .
\end{aligned}
$$

Antrajame diskretiniame modelyje:

$$
\begin{aligned}
& C_{2}=\frac{E_{0}}{\left(1-v_{0}\right)^{2} \cdot H_{s l 2}}= \\
& \frac{40000}{(1-0,3)^{2} \cdot(6+3,6)}=8503 \mathrm{kPa} / \mathrm{m}
\end{aligned}
$$

čia $E_{0}$ - grunto deformaciju modulis; $v_{0}$ - grunto skersinès deformacijos koeficientas; $H_{s l 1}, H_{s l 2}$ - deformuojamo pagrindo sluoksnio storiai pirmajam ir antrajam diskretiniams modeliams.

Deformuojamo pagrindo sluoksnio storis pirmajam skaičiavimo atvejui yra lygus pusei pagrindo tūrinio elemento pločio $H_{s l 1}=7,2 / 2=3,6 \mathrm{~m}$. Antrajam skaičiavimo atvejui apatine riba yra tame pačiame lygyje kaip ir deformuojamo pagrindo sluoksnio pirmojo skaičiavimo atvejui, todèl $H_{s / 2}=6,0+3,6=9,6 \mathrm{~m}$.
Analizuojant skaičiavimo rezultatus yra lyginami abiejų atvejų normaliniai įtempimai y ašies kryptimi sienos ir pamato susijungimo vietoje ( 3 pav.), pamato nuosèdžiai ( 4 ir 5 pav.) ir reaktyviniai spaudimai po pamato padu (6 pav.).

Iš šių rezultatu matome būdingus pamato ir pagrindo nuosèdžius skersiniame pjūvyje (4 pav.). Vidutiniai reaktyviniai spaudimai po pamato padu (išskyrus reaktyviniu spaudimu koncentracijas po pamato pado kraštais) pirmajam skaičiavimo atvejui yra $\sim 21 \%$

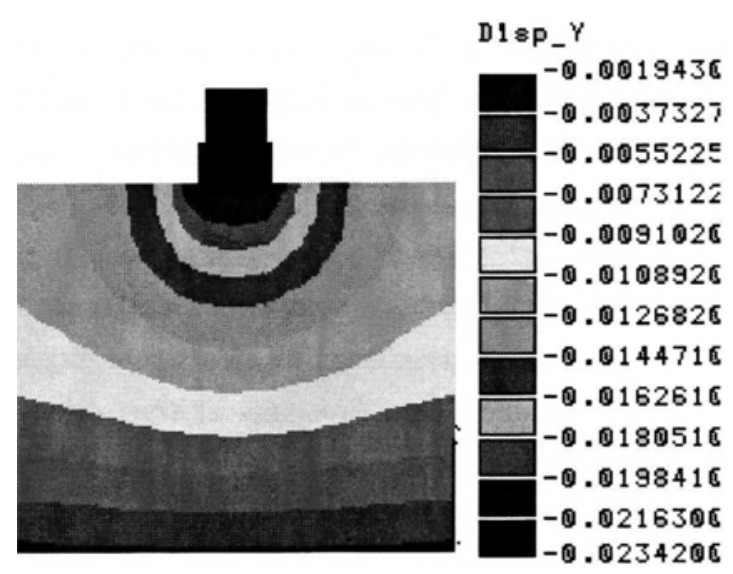

4 pav. Vertikaliujų poslinkių ir nuosèdžių pasiskirstymas skersiniame pamato ir pagrindo pjūvyje

Fig 4. Distribution of the substructure and foundation displacements in $y$ direction (cross-section) 


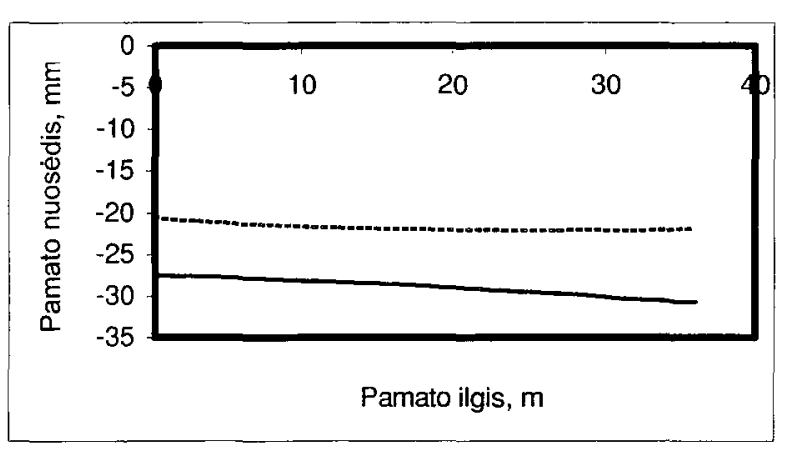

5 pav. Nuosèdžiu po pamato padu pasiskirstymas

Fig 5. Distribution of displacements in $y$ direction under the substructure

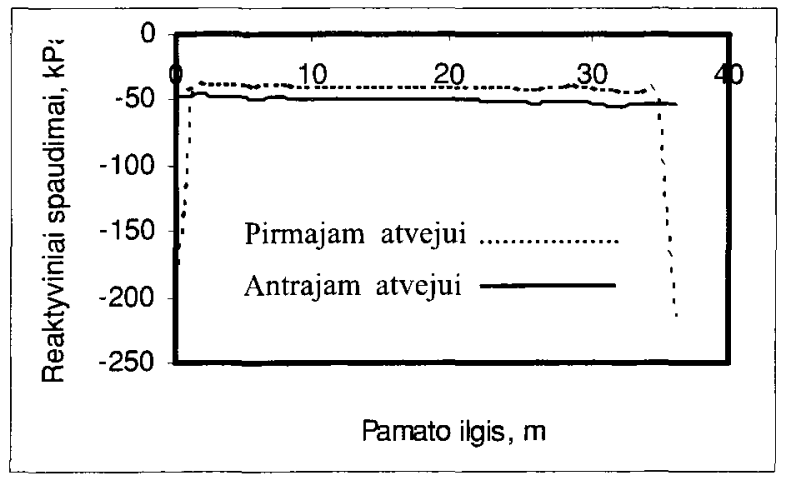

6 pav. Reaktyvinių spaudimų $y$ ašies kryptimi po pamato padu pasiskirstymas

Fig 6. Distribution of normal stresses in $y$ direction under the substructure

mažesni. Skaičiavimo metodas leidžia ivertinti ne tik kontaktiniu itempimy (reaktyvinių spaudimu) netolygu pasiskirstymą skersine pamato kryptimi, bet ir reaktyviniu spaudimu koncentraciją pamato kraštuose, t. y. zonose, kur pirmiausia atsiras plastinès deformacijos, nes čia $\mathbf{p}_{j}(\mathbf{x})>\mathbf{R}_{\boldsymbol{j}}(\mathbf{x})$. Pamato nuosèdžiai pirmajam skaičiavimo atvejui taip pat gaunami $\sim 28 \%$ mažesni. Normaliniai ittempimai $y$ ašies kryptimi ties sienos ir pamato riba abiem skaičiavimo atvejams skiriasi labai nedaug, tik sienos kraštuose, kaip ir po pamatu, pirmuoju skaičiavimo atveju šie itempimai yra didesni.

Normaliniu itempimu $y$ ašies kryptimi netolygus pasiskirstymas ties sienos ir pamato riba (6 pav.) akivaizdžiai rodo, kad pasiūlyta skaičiavimo metodika leidžia ivertinti santykinio sistemos „konstrukcija-pamatas“ standumo pasikeitimą nagrinèjamos sienos ilgyje.

\section{Išvados}

1. Išnagrinètas konstrukcijos ant tampraus pagrindo skaičiavimas kaip sienos pamato ir pagrindo sąveikos uždavinys leidžia pereiti nuo kontaktiniụ tokio tipo uždavinių sprendimo prie itempimų ir deformacijų būvio ivertinimo pagal tamprumo teorijos metodus.

2. Suformuluoti matematiniai modeliai leidžia ivertinti ne tik bendrą sistemos „konstrukcija-pamatas-pagrindas" itempimų deformacijų būvị, bet ir tiksliai atitinka ju praktini realizavimą kompiuterinès programos paketu COSMOS/M.

3. Gauti skaičiavimo rezultatai (pirmasis atvejis) parodé, kad galima ivertinti ne tik itempimų bei poslinkiu pasiskirstymo spektrą konstrukcijoje, bet ir nuosẻdžiụ bei reaktyvinių spaudimų pasiskirstymą pamato skersine, išilgine kryptimis, taip pat pagal pagrindo gyli.

4. Pasiūlyta skaičiavimo metodika leidžia tiksliau ivertinti ne tik konstrukcijos, bet ir gruntinio pagrindo savojo svorio itaka itempimu ir deformaciju pasiskirstymui sistemoje „konstrukcija-pagrindas“.

\section{Literatūra}

1. М. И. Горбунов-Поссадов, Т. А. Матикова, В. И. Соломин. Расчет конструкций на упругом основании. Москва: Стройиздат, 1984. 678 с.

2. J. E. Bowles, Foundation Analysis and Design, $4^{\text {th }}$ Edn. McGraw-Hill, New York, 1988. 750 p.

3. Л. А. Розин. Вариационные постановки задач для упругих систем. Л.: Изд-во Ленингр. ун-та, 1978. 224 с.

4. A. Krutinis. Mathematical models for design of elastic structures on deformable ground // Lithuanian Journal of Computational Mechanics, Vol 33, 1993, p. 108-116.

5. S. Kalanta. Relations and transformations of extremum energy principles for deformable body // Statyba, Nr. 1(9). Vilnius: Technika, 1997, p. 49-64.

6. COSMOS/M. Designer II. A Complete Design Analysis System. Version 1.2. Structural Research and Analysis Corporation. Los Angeles, California. Copyright 1996. 276 p.

Itteikta 20001011

\section{ANALYSIS OF CONSTRUCTION ON ELASTIC FOUNDATION WITH EVALUATION OF ALL SYSTEM DEAD WEIGHT}

\section{A. Grigusevičius, S. Kalanta, A. Krutinis}

Summary

Solution of constructions on an elastic foundation was formulated as the contact problem [1], [2]. With such a for- 
mulation the stress and strain state is investigated at the contact of construction and foundation. Therefore, we can not evaluate the influence of elastic foundation dead weight for stress and strain distribution in the soil. The aim of this article is to solve this pressing problem, which allows to define in more precise way the stress and strain state in the system, and to evaluate not only the dead weight of the construction, but also the dead weight of foundation. The system "construction-substructure-foundation" is investigated as an interaction of separate bodies. Such a formulation allows to go over from solving contact problems to the solution of qualitatively new problems in which the distribution of stresses and strains in foundation along the depth is evaluated. Mathematical models in this article are realised by computer programme COSMOS/M. The stress-strain state is determined by describing the system "wall-substructure-foundation" of elements with different physical-mechanical indices.

Andrius GRIGUSEVIČIUS. PhD student. Dept of Structural Mechanies. Vilnius Gediminas Technical University (VGTU), Saulètekio al. 11, LT-2040 Vilnius, Lithuania. E-mail: a-grig@hotmail.com

A graduate of Vilnius Gediminas Technical University, civil engineer (1998), MSc (2000). Research interests: structural mechanics, analysis and optimisation of elastic-plastic structures on deformable ground.
Stanislovas KALANTA. Doctor, Assoc Prof. Dept of Structural Mechanics. Vilnius Gediminas Technical University (VGTU), Saulettekio al. 11, LT-2040 Vilnius, Lithuania. E-mail: kal@st.vtu.lt

$\mathrm{PhD}$ (1974, structural mechanics). Research visits: SanktPetersburg Polytechnical Institute, Kiev Civil Engineering Institute. Research interests: computational mechanics, finite element method, analysis and optimisation of elastic-plastic structures.

Antanas KRUTINIS. Doctor, Assoc Prof. Dept of Structural Mechanics. Vilnius Gediminas Technical University (VGTU), Sauletekio al. 11, LT-2040 Vilnius, Lithuania. E-mail: akr@st.vtu.lt

PhD (1971, structural mechanics). Research visits: Moscow Civil Engineering Institute, Kiev Civil Engineering Institute, Weimar Higher School of Architecture and Civil Engineering. Research interests: analysis and optimisation of elastic-plastic structures on deformable ground. 